\title{
Genetic testing of PAX8 mutations associated with thyroid dysgenesis in Chinese congenital hypothyroidism patients
}

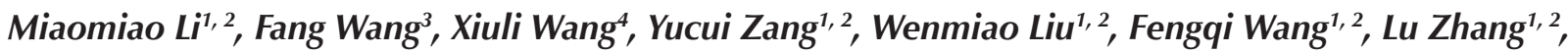 \\ Qian Tang ${ }^{1,2}$, Shiguo Liu', ${ }^{1,}$ Dehua Zhao ${ }^{5}$ \\ ${ }^{1}$ Medical Genetic Department, The Affiliated Hospital of Qingdao University, Qingdao, China \\ ${ }^{2}$ Prenatal Diagnosis Center, The Affiliated Hospital of Qingdao University, Qingdao, China \\ ${ }^{3}$ Department of Endocrinology and Metabolism, The Affiliated Hospital of Qingdao University, Qingdao, China \\ ${ }^{4}$ Neonatal Disease Screening Center, Xuzhou Maternity and Child Health Care Hospital, Xuzhou, China \\ ${ }^{5}$ Department of Henan Newborn Screening Center, The Third Affiliated Hospital of Zhengzhou University, Zhengzhou, China
}

\begin{abstract}
Introduction: Thyroid dysgenesis (TD) is the main cause of congenital hypothyroidism (CH), affecting nearly 1 in 2000-3000 newborns worldwide, as the most common neonatal endocrine disorder. Paired box gene 8 (PAX8), expressed during all stages of thyroid follicular cell, plays a key role in thyroid morphogenesis by a complex regulatory network. In conclusion, the genetic mechanism of $P A X 8$ mutant in TD is still ambiguous; therefore, further research is needed.

Material and methods: Blood samples were collected from 289 TD patients in Shandong Province, China. Genomic DNA was extracted from peripheral blood. All the exons of $P A X 8$ along with their exon-intro boundaries were amplified by PCR and analysed by Sanger sequencing. Results: We identified three novel PAX8 nonsense mutations in three patients by sequence analysis of PAX8: Patient 1 (c.285C $>$ G, p.Tyr95Ter), Patient 2 (c.747T > G, p.Tyr249Ter), and Patient 3 (c.786C >A, p.Tyr262Ter). All the three patients carrying PAX8 variants had obvious clinical phenotypes of thyroid anomaly, such as hypoplasia and athyreosis.

Conclusion: We conducted the largest worldwide PAX8 mutation screening so far in TD patients. Three presumably pathogenic PAX 8 mutations were detected in $289 \mathrm{TD}$ cases for the first time, showing the mutation rate of PAX8 is $1.04 \%$ in Chinese TD patients. In addition, our study expands the gene mutation spectrum of TD. (Endokrynol Pol 2020; 71 (2): 153-159)
\end{abstract}

Key words: thyroid dysgenesis; paired box gene 8; mutation; Sanger sequencing

\section{Introduction}

Congenital hypothyroidism $(\mathrm{CH})$ is the most common neonatal endocrine disorder affecting nearly 1 in 2000-3000 newborns worldwide, and the severe deficiency of thyroid hormone can lead to mental retardation and growth failure if not treated in a timely manner [1]. Thyroid dysgenesis (TD), the main cause of $\mathrm{CH}$, accounting for $80-85 \%$ of $\mathrm{CH}$ cases, caused by the abnormalities of thyroid gland development and migration, can be divided into three subtypes (agenesis, ectopy, and hypoplasia) according to the morphology and location of the thyroid gland [2].

In humans, thyroid development can be divided into six stages: the thyroid anlage assembled by thyroid progenitors (E20-22); the appearance of the thyroid bud (E24); the migration of the thyroid (E30-40); the completion of thyroid migration (E45-50); thyroid bilobation and folliculogenesis (E60); and the completion of differentiation and organogenesis (E70) [3]. In this process, thyroid morphogenesis is a coordinated spatial and tem- poral process, which, when altered, can result in agenesis, ectopy, and hypoplasia [4,5]. Various transcription factors play important roles in the thyroid development, especially haematopoietically expressed homeobox gene (HHEX), thyroid transcription factor 1 (TTF1/NKX2.1), thyroid transcription factor 2 (TTF2/FOXE1), and paired box gene 8 (PAX8), the expression of which can be detected at E20 and forms a complex regulatory network to induce morphological changes [6]. PAX8 regulates the expression of FOXE1, HHEX, DUOX2, TG, and TPO [7-9] but can be regulated by HHEX and NKX2.1 simultaneously. In addition, $P A X 8$ expression is autoregulated; the cross-regulatory network ensures that $P A X 8$ is a master regulator in thyroid development. Furthermore, mutations in PAX8 combined with NKX2.1, FOXE1, NKX2.5, TSHR, NTN1, JAG1, BOREALIN, and GLIS3 have been identified in patients with TD [10].

PAX8 (NM_003466.4), located on human chromosome 2q12-q14, can be divided into 12 exons. The PAX8 protein has a bipartite functionality consisting of a highly conserved DNA binding region in N-terminal 
and a transactivation region in C-terminal [11, 12]. Expressed during all stages of thyroid follicular cell (TFC) and in adults [13], PAX8 plays a key role in thyroid morphogenesis. In ax $^{8 /-}$ mice at E11.5, thyroid primordium appears to be much smaller (hypoplastic thyroid) than in wild-type and is essentially undetectable at E12.5 follicular cells $[14,15]$. In vitro, PAX8 is a master gene for the regulation of the thyroid differentiated phenotype in several thyroid-derived cell lines [16]. Therefore, PAX8 is required for thyroid bud survival and TFC differentiation, and mutations in PAX8 may lead to TD [16, 17]. In the present study, we aimed to identify potential pathogenic PAX8 mutations in 289 Chinese children with TD, thereby providing insights into its aetiology.

\section{Material and methods}

\section{Patients}

Sixty-three TD patients were collected for screening variations in exon 3 and exon 4 of $P A X 8$ in our preliminary study. In this research, we collected another 289 patients with TD identified through screening of newborns in Shandong Province from January 2015 to November 2017. Neonatal screening for $\mathrm{CH}$ was proceeded in all of the subjects 72 hours after birth with blood samples from the heel. Then the concentrations of thyroid-stimulating hormone (TSH), free/total triiodothyronine (T3), and free/total thyroxine (T4) in serum were detected, respectively, using electro-chemiluminescence kits: Elecsys TSH, Elecsys FT3III, and Elecsys FT4III (Roche, German). The diagnosis of $\mathrm{CH}$ was based on a high serum TSH level (TSH $\geq 10 \mathrm{mIU} / \mathrm{L}$ ) and a low fT4 level (fT4 $<12 \mathrm{pmol} / \mathrm{L})$. When the $\mathrm{CH}$ patients were three years old, they underwent thyroid echography and scintigraphy to establish the cause of $\mathrm{CH}$. All the 289 patients selected for further research had been diagnosed as TD. The present study was approved by the Ethics Committee of the Affiliated Hospital of Qingdao University (2013-qdfy22). Informed consent was obtained from all individuals included in this study. The research related to human use complied with all the relevant national regulations and institutional policies, was in accordance the tenets of the Helsinki Declaration, and was approved by the authors' Institutional Review Board or equivalent committee.

\section{Methods}

Genomic DNA was extracted from peripheral blood with TIANGEN blood kit (TIANGEN, Beijing, China). All the exons of PAX8 along with their exon-intro boundaries were amplified by PCR, with the specific primer as Table 1 . The PCR reaction solution contained

Table 1. The primer sequence for polymerase chain reaction (PCR) of PAX8

\begin{tabular}{|c|c|c|c|c|}
\hline Primer & Sequence & $\mathrm{Tm}$ & PCR product & Product length [bp] \\
\hline E1-F & AGGGCATCCTACAGAGACCA & 55 & \multirow{2}{*}{ Exon 1} & \multirow{2}{*}{547} \\
\hline $\mathrm{E} 1-\mathrm{R}$ & TCCCGTTTAACTTGGGAGGG & 56 & & \\
\hline E2-F & TССТССТАСTCCTGGCAGAC & 60 & \multirow{2}{*}{ Exon 2} & \multirow{2}{*}{471} \\
\hline E2-R & AGAGATCСССТСАССGАТСC & 60 & & \\
\hline E3-F & TTGGGAGTGAGAACTGGGGA & 60 & \multirow{2}{*}{ Exon 3} & \multirow{2}{*}{421} \\
\hline E3-R & GGGGAATTCTCTAGCTGCCC & 60 & & \\
\hline E4-F & GAGGCCTTTAGCAGAGGGTG & 60 & \multirow{2}{*}{ Exon 4} & \multirow{2}{*}{451} \\
\hline E4-R & GACACCAGAGGCTGCTTTCT & 60 & & \\
\hline E5-F & GGGTGTCAAAAAGGCGACTG & 60 & \multirow{2}{*}{ Exon 5} & \multirow{2}{*}{372} \\
\hline E5-R & TCAGTGAATCTGCCCTGGGA & 60 & & \\
\hline E6-F & АСТСТСАСТСССТGАСССТС & 60 & \multirow{2}{*}{ Exon 6} & \multirow{2}{*}{446} \\
\hline E6-R & CACATGCAGAGCCCCTACAA & 60 & & \\
\hline E7-F & GCССТTTTTCTCССТССАСА & 60 & \multirow{2}{*}{ Exon 7} & \multirow{2}{*}{549} \\
\hline E7-R & ATCATCAGGTTGTGCTGCCA & 60 & & \\
\hline E8-F & TGCCGAGTGGAGTTGAGAAC & 60 & \multirow{2}{*}{ Exon 8} & \multirow{2}{*}{414} \\
\hline E8-R & CTGGGCCCACCTGGC & 59 & & \\
\hline $\mathrm{E} 9-\mathrm{F}$ & CTTGGCTTGTGCGTGTTCC & 60 & \multirow{2}{*}{ Exon 9} & \multirow{2}{*}{401} \\
\hline E9-R & CTCCAAAAGTTGCCGGAGGA & 60 & & \\
\hline $\mathrm{E} 10-\mathrm{F}$ & GTGGGAATGGCATGGAGGAA & 60 & \multirow{2}{*}{ Exon 10} & \multirow{2}{*}{468} \\
\hline E10-R & GTCTCAGCCCСTCCCTTTTC & 60 & & \\
\hline E11-F & СТССААСТGТСТССССААСС & 60 & \multirow{2}{*}{ Exon 11} & \multirow{2}{*}{452} \\
\hline E11-R & CATGGGCTTGAGAAGCAGGA & 60 & & \\
\hline E12-F-1 & CAGGGAAGGCTATGGTGCAA & 60 & \multirow{2}{*}{ Exon 12-1 } & \multirow{2}{*}{1508} \\
\hline E12-R-1 & GTGAGGTACCCAGCGTTCAA & 60 & & \\
\hline $\mathrm{E} 12-\mathrm{F}-2$ & CATCAGAGCTGAGTAGCCGA & 59 & \multirow{2}{*}{ Exon $12-2$} & \multirow{2}{*}{1389} \\
\hline E12-R-2 & ACAGTCAACAAACACCCGCT & 60 & & \\
\hline
\end{tabular}




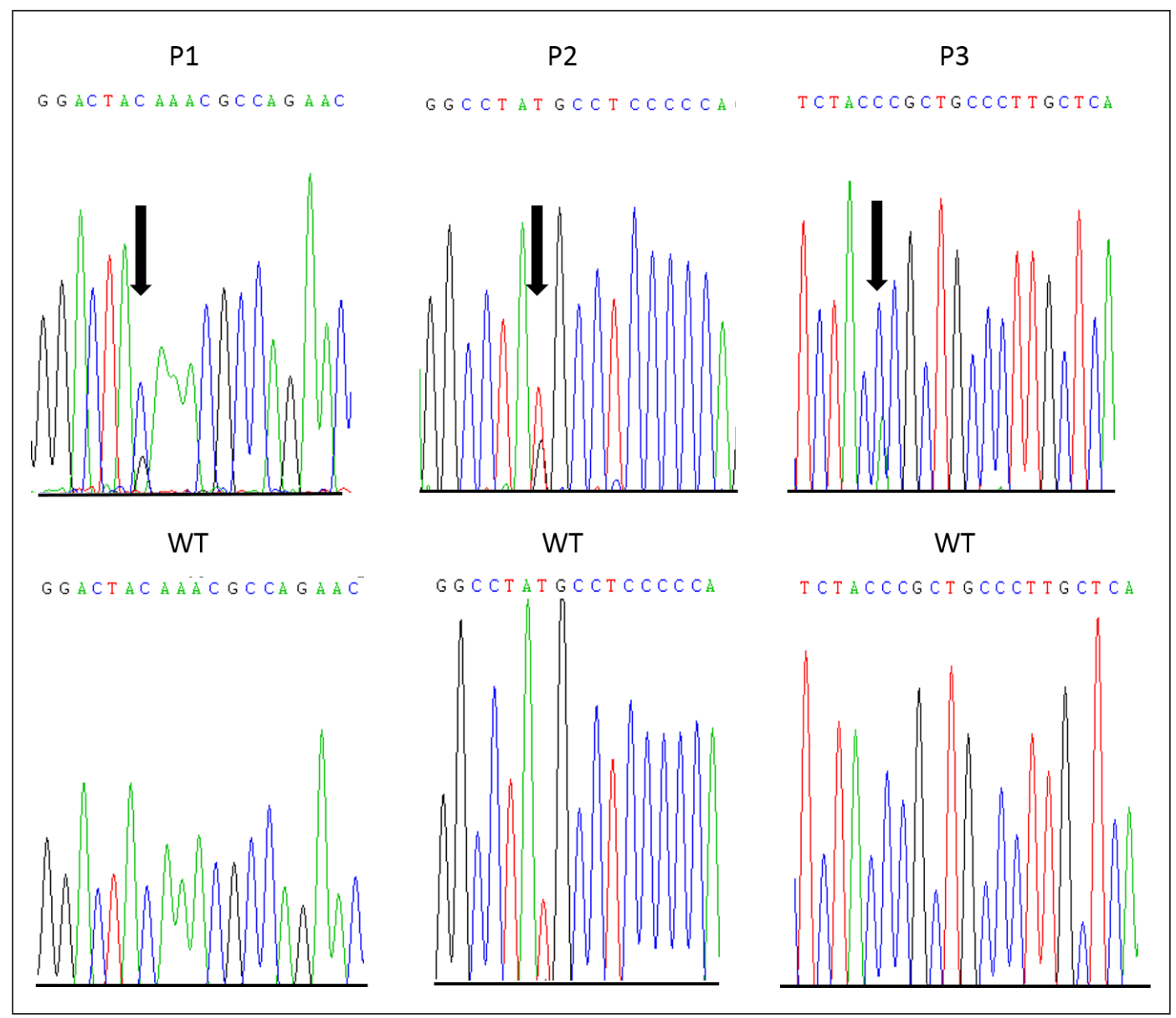

Figure 1. Sequence maps of PAX8 gene. P1 — sequence of Patient 1 with the PAX8 variant c.C285G; P2 — sequence of Patient 2 with the PAX8 variant c. T747G; P3 - sequence of Patient 3 with the variant $c . C 786 A ; C 1, C 2$, and C3 is the corresponding sequence in the general population

$1 \times$ TransStart ${ }^{\circledR}$ FastPfu buffer with $0.2 \mathrm{mM}$ dNTP, 1.25 units of TransStart ${ }^{\circledR}$ FastPfu DNA polymerase, 50 ng Genomic DNA, and $0.2 \mu \mathrm{M}$ of each primer; the total volume was $25 \mu \mathrm{l}$. The procedure of the PCR amplification was as follows: step 1 - denaturation at $95^{\circ}$ for $2 \mathrm{~min}$; step 2 - denaturation at $95^{\circ}$ for $20 \mathrm{~s}$; step 3 - annealing at primer-specific temperatures for $20 \mathrm{~s}$; step 4 - extension at $72^{\circ}$ for $20 \mathrm{~s}$ or $60 \mathrm{~s}$; step 5 - incubated at $72^{\circ}$ for $5 \mathrm{~min}$. Steps 2 to 4 were cycled 35 times. A BigDye ${ }^{\circledR}$ Terminator Cycle Sequencing Kit and automated sequencer $\mathrm{ABI} 3730 \mathrm{XL}$ were used for the sequencing reaction of the PCR products. The sequencing results were interpreted using BioEdit software.

\section{Results and clinical report}

\section{Genetic screening of PAX8 mutation}

A total of 289 TD patients were enrolled in this study, the ratio of male to female was 1:1.05. According to the location and size of the thyroid gland, TD was classified into agenesis (120 cases, $41.5 \%$ ), ectopy (94 cases, $32.5 \%$ ), and hypoplasia (75 cases, $26 \%$ ). Sanger sequencing analysis of PAX8 leading to the discovery of three novel PAX8 variants in three patients: Patient 1 (NG_012384.1 (NM_003466.4): c.285C > G, p.Tyr95Ter); Patient 2 (NG_012384.1 (NM_003466.4): c.747T>G, p.Tyr249Ter), and Patient 3 (NG_012384.1 (NM_003466.4): c.786C > A, p.Tyr262Ter); the sequence maps of the variants is shown in Figure 1. All the variants located in the evolutionary conserved protein domains of PAX8 were not detected in 200 control individuals or in the Exome Sequencing Project (ESP) or the 1000 Genomes Project databases.

\section{Analysis of the relationship between genotype and phenotype}

The three patients carrying PAX8 mutations had obvious clinical phenotype of thyroid anomaly, such as hypoplasia and athyreosis (Tab. 2). The medical records in detail are as follows.

Patient 1 , a female infant with p.Tyr95Ter mutation in $P A X 8$, was born at 39 weeks of gestation by vaginal delivery with $3250 \mathrm{~g}$ birth weight. High TSH levels (208 $\mu \mathrm{IU} / \mathrm{mL}$ ) were detected at five days of age during neonatal screening; she was recalled at 18 days of age for further evaluation, and the TSH serum level had increased to $384 \mu \mathrm{IU} / \mathrm{mL}$, the FT3 level was $2.28 \mathrm{pmol} / \mathrm{L}$, and the FT4 level was $4.12 \mathrm{pmol} / \mathrm{L}$. There was no fam- 
Table 2. Clinical characteristics of four congenital hypothyroidism (CH) patients carrying genetic variants

\begin{tabular}{lcccccc}
\hline Subject & Age & Sex & TSH [ulU/mL] & FT4 [pmol/L] & Variant & Clinical phenotype \\
\hline Patient 1 & 10 & Girl & 384 & 4.12 & p.Tyr95Ter & Hypoplasia \\
\hline Patient 2 & 12 & Girl & 284 & 8.71 & p.Tyr249Ter & Hypoplasia \\
\hline Patient 3 & 13 & Boy & 294 & 2.8 & p.Tyr262Ter & Athyreosis \\
\hline
\end{tabular}

TSH — thyroid-stimulating hormone; FT4 — free thyroxine

ily history of thyroid disease. Tc-99 m scans confirmed hypoplasia. Levothyroxine $(\mathrm{L}-\mathrm{T} 4)$ replacement therapy was started at an initial dose of $25 \mu \mathrm{g}$ per day. We lost contact with this patient until 3.5 years of age. Then we contacted her parents and learned that the patient was receiving L-T4 $33.3 \mu$ g replacement therapy. Half a year after withdrawal of L-T4 therapy, her TSH levels were outside the normal range for her age (five years). Therefore, L-T4 $25 \mu \mathrm{g}$ replacement therapy has been needed until now.

Patient 2 with p.Tyr249Ter mutation was a female who weighed $3000 \mathrm{~g}$ at birth by vaginal delivery. She was recalled for further analysis after high TSH levels ( $232 \mu \mathrm{IU} / \mathrm{mL}$ ) were detected at six days of age during neonatal screening. At 13 days of age, TSH levels were $284 \mathrm{uIU} / \mathrm{L}, \mathrm{FT} 3$ levels were $4.31 \mathrm{pmol} / \mathrm{l}$, and FT4 levels were $8.71 \mathrm{pmol} / \mathrm{L}$. Therefore, $\mathrm{L}-\mathrm{T} 425 \mu \mathrm{g}$ replacement therapy was started immediately with re-examination of TSH levels per mouth. At two years old, she was diagnosed with permanent $\mathrm{CH}$, and persistent treatment was prescribed because TSH levels were outside the normal range after a four-week withdrawal of L-T4 therapy. Tc-99 m scans showed hypoplasia. L-T4 30 ug replacement therapy was restarted. She is now 12 years old, and her physical and intellectual development are normal. The dosage of L-T4 was increased to $62.5 \mu \mathrm{g}$ per day.

Patient 3 was a male subject with a p.Tyr262Ter mutation. He was born at full-term by caesarean delivery, and his birth weight was $3750 \mathrm{~g}$. Routine neonatal screening showed a high TSH level of $186 \mu \mathrm{IU} / \mathrm{mL}$ at three days of age. Then, the patient was recalled at 19 days to review the serum TSH level which had increased to $294 \mu \mathrm{IU} / \mathrm{mL}$ but the FT4 (2.8 pmol/L) and FT3 (2.2 pmol/L) levels were both low. L-T4 replacement therapy was started immediately at a dose of $25 \mu \mathrm{g}$. Tc-99 m scans detected an athyreosis. At two years of age, he was diagnosed with permanent $\mathrm{CH}$. Now he is four years old, with normal physical and mental development.

\section{Discussion}

PAX8 induces thyroid morphogenesis by cooperating with other transcription factors, such as HHEX, NKX2.1, and FOXE1. The regulatory function of PAX8 is closely related to its molecular structure, which consists of two functional domains: a paired box domain for DNA binding; and an octapeptide and a residual paired type homeodomain for transaction. The paired box domain consists of 128 amino acids positioned between 9 and 137, the octapeptide is between 180 and 187, and the residual paired type homeodomain is between 228 and 250, all the domains are highly conserved in human PAX protein family $[12,18]$.

The first description about PAX8 variants was conducted by Macchia in 1998; three mutations in two sporadic patients (p.R31H, p.L62R) and one familial case (p.R108X) resulted in severe reduction of the DNA-binding activity of $P A X 8$, causing thyroid hypoplasia [19]. Vilain identified p.C57Y in a TD patient; the mutation resulted in loss of the ability to activate thyroid peroxidase (TPO) gene [20]. In these cases, $P A X 8$ mutations were inherited in an autosomal dominant manner. However, the same mutation site in a familial case may result in different clinical phenotypes. Esperante described a thyroid hypoplasia patient and his family carrying mutation p.T225M, while the father, brother, and sister were asymptomatic; and a thyroid agenesis patient and her mother carrying mutation p.G336S, while the mother was unaffected, suggesting that the variable penetrance or expressivity of the mutational carrier can be modulated not only by genetic but also by epigenetic factors [18]. In conclusion, the genetic mechanism of PAX8 mutant in TD is still ambiguous; therefore, more research is needed in future studies.

In present study, all the patients carrying the novel variant of $P A X 8$ had symptoms of obvious abnormal thyroid. Variant Y95X located at paired box domain, variant Y249X at homodomain, and variant Y262X at transactivation domain of PAX8 protein (Figure 2) led to PAX8 dysfunction, with most or all of transactivation domain lost. Carrying the heterozygous variant, P1-3 was detected with high level of TSH during neonatal screening, and then P1 and P2 were diagnosed as hypoplasia by ultrasound examination; P3 was athyreosis. It is possible that the nonsense variants led to nonsense mediated decay of the mutated mRNA, thus the TD phenotype could be due to haploinsufficiency of PAX8 protein. The actual functional consequences of PAX8 


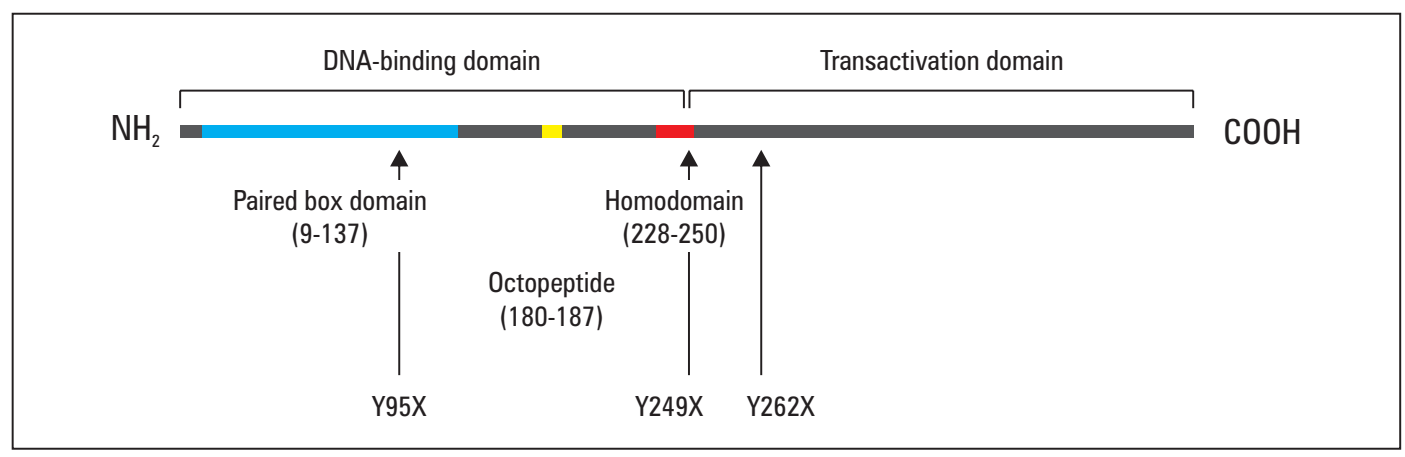

Figure 2. Schematic representation of human PAX8 protein domains

truncating mutations are yet to be further investigated, and thus more experiments in vitro are still needed for pathologic study.

Because PAX8 plays a key role in thyroid morphogenesis, many researches have screened PAX8 mutations in a large number of $\mathrm{CH}$ patients to get the mutational frequencies and relationship between genotypes and phenotypes. Kumorowicz-Czoch found two novel heterozygous substitutions (c.68G > A, p.G23D; c. ${ }^{*} 416 \mathrm{C}>\mathrm{T}$ ) in 48 Polish $\mathrm{CH}$ patients, and the PAX8 mutation rate is 4.17\% [21], while Al Taji E identified a novel mutation (c.155G >C, p.R52P) in $170 \mathrm{CH}$ patients, and the PAX8 mutation rate in the Czech Republic is $0.6 \%$ [22]. In addition, Ramos HE analysed 35 patients with thyroid hypoplasia in southern Brazil and identified a patient with PAX8 mutation (c.155G >C; p.R52P), and suggested the mutation rate to be $2.9 \%$ [23]. Cangul and Kirsten Lanzerath did not find any PAX8 mutation in $120 \mathrm{CH}$ patients in Pakistan and the United Kingdom and $95 \mathrm{CH}$ patients in south-west Germany, respectively [24, 25], showing the low mutation rate of $P A X 8$ in these countries. All these findings confirmed the contribution of $P A X 8$ mutations to the aetiology of $\mathrm{CH}$ with a variable penetrance, and rare overall incidence.

In 2012, we analysed exon3 and exon4 of PAX8 in $300 \mathrm{CH}$ patients, and then reported a heterozygous missense mutation (c.G92>A, p.R31H) and a variation (c.122G>T, p.G41V) in PAX8, showing that the PAX8 mutation rate $(0.67 \%)$ is very low in $\mathrm{CH}$ patients in China [26]. In 2015, we collected 63 TD patients and found a heterozygous missense de novo mutation (c.155G > C, p.R52P) in PAX8 by sequencing exon 3 and exon4; the mutation rate in Chinese TD patients is $1.59 \%$ [27]. The mutation rate of $P A X 8$ in TD patients is obviously higher in $\mathrm{CH}$ patients, illustrating $P A X 8$ induced $\mathrm{CH}$ by influencing thyroid development or migration from a different aspect. To further determine the mutational frequencies of PAX8 in Chinese
TD patients, we expanded the sample size to 289 and analysed all the 12 exons and exon-intro boundaries. Ultimately, we discovered three novel variants; the mutation rate was $1.03 \%$.

\section{Conclusion}

We conducted the largest worldwide PAX 8 mutation screening so far in TD patients, and three novel PAX8 nonsense variants were identified in three of $289 \mathrm{TD}$ cases; the mutation rate of $P A X 8$ was $1.03 \%$. However, there are still two limitations in this study: first, we did not construct the three variants for functional verification; and second, we did not make the genetic analysis in familial cases due to lack of samples from their parents. Therefore, it is necessary to explore the mechanism for the effects of mutations and screen the mutations of $P A X 8$ among large samples in future research.

\section{Acknowledgment}

We thank all subjects for their collaborative participation in this study.

\section{Conflict of interest}

The authors declare no potential conflict of interest

\section{Data accessibility}

The data used to support the findings of this study are included within the article.

\section{Funding}

This study was supported by the National Natural Science Foundation of China (81741073, 81500689, 81470044, and 81170812) and the National Key Research and Development Program of China under Grant No. 2016YFC1000300 and the Key Research and Development Program of Shandong under Grant No. 2016GSF201228. 


\section{References}

1. Mamun M, Nahar N, Salekin M, et al. Thyroid Hormonal Status in Newly Diagnosed Type 2 Diabetes Mellitus. Bangl J Nucl Med. 2018; 20: 1-27, doi: $10.3329 /$ bjnm.v20i1.36851.

2. Nishi M. Diabetes mellitus and thyroid diseases. Diabetol Int. 2018; 9(2): 108-112, doi: 10.1007/s13340-018-0352-4., indexed in Pubmed: 30603357

3. Donckier JE. Endocrine diseases and diabetes. In: Pickup JC, Williams G. ed. Diabetes Mellitus. Blackwell Publishing Company, Chichester 2003: 21-27.

4. Biondi B, Kahaly GJ, Robertson RP. Thyroid Dysfunction and Diabetes Mellitus: Two Closely Associated Disorders. Endocr Rev. 2019; 40(3): 789-824, doi: 10.1210/er.2018-00163, indexed in Pubmed: 30649221.

5. Chutia H, Bhattacharyya $H$, Ruram AA, et al. Evaluation of thyroid function in type 2 diabetes in north-eastern part of India: A hospital-based study. J Family Med Prim Care. 2018; 7(4): 752-755, doi: 10.4103/jfmpc. jfmpc_292_17, indexed in Pubmed: 30234048.

6. Chawla A, Chawla R, Jaggi S. Microvasular and macrovascular complications in diabetes mellitus: Distinct or continuum? Indian J Endocrinol Metab. 2016; 20(4): 546-551, doi: 10.4103/2230-8210.183480, indexed in Pubmed: 27366724.

7. Solomon SD, Chew E, Duh EJ, et al. Diabetic Retinopathy: A Position Statement by the American Diabetes Association. Diabetes Care. 2017; 40(3): 412-418, doi: 10.2337/dc16-2641, indexed in Pubmed: 28223445.

8. Zalecenia kliniczne dotyczace postepowania u chorych na cukrzyce Stanowisko Polskiego Towarzystwa Diabetologicznego. Diabetologia Praktyczna. 2018; 4(1): 1-94.

9. Sheldon J. Laboratory testing in autoimmune rheumatic diseases. Best Pract Res Clin Rheumatol. 2004; 18(3): 249-269, doi: 10.1016/j. berh.2004.03.007, indexed in Pubmed: 15158740.

10. McCoy L, Tsunoda I, Fujinami RS. Multiple sclerosis and virus induced immune responses: autoimmunity can be primed by molecular mimicry and augmented by bystander activation. Autoimmunity. 2006; 39(1): 9-19, doi: 10.1080/08916930500484799, indexed in Pubmed: 16455578.

11. Guilherme L, Kalil J. Rheumatic fever: the $\mathrm{T}$ cell response leading to autoimmune aggression in the heart. Autoimmun Rev. 2002; 1(5): 261-266, doi: 10.1016/s1568-9972(02)00062-9, indexed in Pubmed: 12848978.

12. Hayter SM, Cook MC. Updated assessment of the prevalence, spectrum and case definition of autoimmune disease. Autoimmun Rev. 2012; 11(10): 754-765, doi: 10.1016/j.autrev.2012.02.001, indexed in Pubmed: 22387972.

13. Sfriso P, Ghirardello A, Botsios C, et al. Infections and autoimmunity: the multifaceted relationship. J Leukoc Biol. 2010; 87(3): 385-395, doi: 10.1189/jlb.0709517, indexed in Pubmed: 20015961.

14. Desai MK, Brinton RD. Autoimmune Disease in Women: Endocrine Transition and Risk Across the Lifespan. Front Endocrinol (Lausanne). 2019; 10: 265, doi: 10.3389/fendo.2019.00265, indexed in Pubmed: 31110493.

15. Golden SH, Robinson KA, Saldanha I, et al. Clinical review: Prevalence and incidence of endocrine and metabolic disorders in the United States: a comprehensive review. J Clin Endocrinol Metab. 2009; 94(6): 1853-1878, doi: 10.1210/jc.2008-2291, indexed in Pubmed: 19494161.

16. Iddah MA, Macharia BN. Autoimmune thyroid disorders. ISRN Endocrinol. 2013; 2013: 509764, doi: 10.1155/2013/509764, indexed in Pubmed: 23878745.

17. Sawicka-Gutaj N, Zybek-Kocik A, Klimowicz A, et al. Circulating Visfatin in Hypothyroidism Is Associated with Free Thyroid Hormones and Antithyroperoxidase Antibodies. Int J Endocrinol. 2016; 2016: 7402469, doi: 10.1155/2016/7402469, indexed in Pubmed: 26884761.

18. Delemer B, Aubert JP, Nys P, et al. An observational study of the initial management of hypothyroidism in France: the ORCHIDÉE study. Eur J Endocrinol. 2012; 167(6): 817-823, doi: 10.1530/EJE-11-1041, indexed in Pubmed: 23034782.

19. Caturegli P, De Remigis A, Rose NR. Hashimoto thyroiditis: clinical and diagnostic criteria. Autoimmun Rev. 2014; 13(4-5): 391-397, doi: 10.1016/j. autrev.2014.01.007, indexed in Pubmed: 24434360.

20. Bloodworth J. Diabetic retinopathy. Diabetes. 1962; 11: 1-22, indexed in Pubmed: 13870120.

21. Wolter JR. Diabetic retinopathy. Am J Ophthalmol. 1961; 51: 1123-1141, doi: 10.1016/0002-9394(61)91802-5, indexed in Pubmed: 13786453.

22. Cunha-Vaz J. Neurodegeneration as an early event in the pathogenesis of Diabetic Retinopathy: A multicentric, prospective, phase II-III, randomised controlled trial to assess the efficacy of neuroprotective drugs administered topically to prevent or arrest Diabetic Rethinopathy. EUROCONDOR — EU FP7 Project. Acta Ophthalmol. 2012; 90(249): 0-0, doi: 10.1111/j.1755-3768.2012.2825.x.

23. Antonetti DA, Klein R, Gardner TW. Diabetic retinopathy. N Engl J Med. 2012; 366(13): 1227-1239, doi: 10.1056/NEJMra1005073, indexed in Pubmed: 22455417.

24. Cunha-Vaz J, Ribeiro L, Lobo C. Phenotypes and biomarkers of diabetic retinopathy. Prog Retin Eye Res. 2014; 41: 90-111, doi: 10.1016/j.preteyeres.2014.03.003, indexed in Pubmed: 24680929.

25. Ratajczak W, Tokarz-Deptuła B, Deptuła W. Immunologia oka. Postepy Hig Med Dosw (online). 2018; 72: 318-325.
26. Abcouwer SF, Gardner TW. Diabetic retinopathy: loss of neuroretinal adaptation to the diabetic metabolic environment. Ann NY Acad Sci. 2014; 1311: 174-190, doi: 10.1111/nyas.12412, indexed in Pubmed: 24673341.

27. Sohn EH, van Dijk HW, Jiao C, et al. Retinal neurodegeneration may precede microvascular changes characteristic of diabetic retinopathy in diabetes mellitus. Proc Natl Acad Sci USA. 2016; 113(19): E2655-E2664, doi: 10.1073/pnas.1522014113, indexed in Pubmed: 27114552.

28. Eshaq RS, Aldalati AMZ, Alexander JS, et al. Diabetic retinopathy: Breaking the barrier. Pathophysiology. 2017; 24(4): 229-241, doi: 10.1016/j. pathophys.2017.07.001, indexed in Pubmed: 28732591.

29. Rusin P, Majsterek I. Molekularne podstawy retinopatii cukrzycowej. Postępy Hig. Med. Dośw. (online). 2007; 61: 786-796.

30. Yau JWY, Rogers SL, Kawasaki R, et al. Meta-Analysis for Eye Disease (META-EYE) Study Group. Global prevalence and major risk factors of diabetic retinopathy. Diabetes Care. 2012; 35(3): 556-564, doi: 10.2337/dc11-1909, indexed in Pubmed: 22301125.

31. Kollias AN, Ulbig MW. Diabetic retinopathy: Early diagnosis and effective treatment. Dtsch Arztebl Int. 2010; 107(5): 75-83; quiz 84, doi: 10.3238/arztebl.2010.0075, indexed in Pubmed: 20186318.

32. Wu L, Fernandez-Loaiza P, Sauma J, et al. Classification of diabetic retinopathy and diabetic macular edema. World J Diabetes. 2013; 4(6): 290-294, doi: 10.4239/wjd.v4.i6.290, indexed in Pubmed: 24379919.

33. Fong DS, Aiello L, Gardner TW, et al. Diabetic Retinopathy. Diabetes Care. 2003; 26(Supplement 1): S99-S102, doi: 10.2337/diacare.26.2007. s99, indexed in Pubmed: 12502630 .

34. Rajalakshmi R, Prathiba V, Mohan V. Does tight control of systemic factors help in the management of diabetic retinopathy? Indian J Ophthalmol. 2016; 64(1): 62-68, doi: 10.4103/0301-4738.178146, indexed in Pubmed: 26953026

35. Pradeepa R, Anitha B, Mohan V, et al. Risk factors for diabetic retinopathy in a South Indian Type 2 diabetic population - the Chennai Urban Rural Epidemiology Study (CURES) Eye Study 4. Diabet Med. 2008; 25(5): 536-542, doi: 10.1111/j.1464-5491.2008.02423.x, indexed in Pubmed: 18346159

36. Shichiri M, Kishikawa H, Ohkubo Y, et al. Long-term results of the Kumamoto Study on optimal diabetes control in type 2 diabetic patients. Diabetes Care. 2000; 23(Suppl 2): B21-B29, indexed in Pubmed: 10860187.

37. Chew EY, Ambrosius WT, Davis MD, et al. ACCORD Study Group, ACCORD Eye Study Group. Effects of medical therapies on retinopathy progression in type 2 diabetes. N Engl J Med. 2010; 363(3): 233-244, doi: 10.1056/NEJMoa1001288, indexed in Pubmed: 20587587.

38. Nathan DM, Genuth S, Lachin J, et al. Diabetes Control and Complications Trial Research Group. The effect of intensive treatment of diabetes on the development and progression of long-term complications in insulin-dependent diabetes mellitus. N Engl J Med. 1993; 329(14): 977-986, doi: 10.1056/NEJM199309303291401, indexed in Pubmed: 8366922.

39. Intensive blood-glucose control with sulphonylureas or insulin compared with conventional treatment and risk of complications in patients with type 2 diabetes (UKPDS 33). UK Prospective Diabetes Study (UKPDS) Group. Lancet. 1998; 352(9131): 837-853, indexed in Pubmed: 9742976.

40. Matuszewski W, Bandurska-Stankiewicz E, Modzelewski R, et al. Diagnosis and treatment of diabetic retinopathy - historical overview. Clin Diab. 2017; 6(5): 182-188, doi: 10.5603/dk.2017.0030.

41. Silva PS, Cavallerano JD, Sun JK, et al. Effect of systemic medications on onset and progression of diabetic retinopathy. Nat Rev Endocrinol. 2010; 6(9): 494-508, doi: 10.1038/nrendo.2010.122, indexed in Pubmed: 20664533.

42. Kozak I, Luttrull JK. Modern retinal laser therapy. Saudi J Ophthalmol. 2015; 29(2): 137-146, doi: 10.1016/j.sjopt.2014.09.001, indexed in Pubmed: 25892934.

43. Yun SH, Adelman RA. Recent developments in laser treatment of diabetic retinopathy. Middle East Afr J Ophthalmol. 2015; 22(2): 157-163, doi: 10.4103/0974-9233.150633, indexed in Pubmed: 25949072.

44. Zhao Y, Singh RP. The role of anti-vascular endothelial growth factor (anti-VEGF) in the management of proliferative diabetic retinopathy. Drugs Context. 2018; 7: 212532, doi: 10.7573/dic.212532, indexed in Pubmed: 30181760.

45. Brănisteanu DC, Bilha A, Moraru A. Vitrectomy surgery of diabetic retinopathy complications. Rom J Ophthalmol. 2016; 60(1): 31-36, indexed in Pubmed: 27220230.

46. Papadopoulos N, Martin J, Ruan Q, et al. Binding and neutralization of vascular endothelial growth factor (VEGF) and related ligands by VEGF Trap, ranibizumab and bevacizumab. Angiogenesis. 2012; 15(2): 171-185, doi: 10.1007/s10456-011-9249-6, indexed in Pubmed: 22302382.

47. Hage M, Zantout MS, Azar ST. Thyroid disorders and diabetes mellitus. J Thyroid Res. 2011; 2011: 439463, doi: 10.4061/2011/439463, indexed in Pubmed: 21785689.

48. Perros P, McCrimmon RJ, Shaw G, et al. Frequency of thyroid dysfunction in diabetic patients: value of annual screening. Diabet Med. 1995; 12(7): 622-627, doi: 10.1111/j.1464-5491.1995.tb00553.x, indexed in Pubmed: 7554786. 
49. Hansen D, Bennedbaek FN, Hansen LK, et al. Thyroid function morphology and autoimmunity in young patients with insulin-dependent diabetes mellitus. Eur J Endocrinol. 1999; 140(6): 512-518, doi: 10.1530/eje.0.1400512, indexed in Pubmed: 10366407.

50. Celani MF, Bonati ME, Stucci N. Prevalence of abnormal thyrotropin concentrations measured by a sensitive assay in patients with type 2 diabetes mellitus. Diabetes Res. 1994; 27(1): 15-25, indexed in Pubmed: 7648793.

51. Ray S, Ghosh S. Thyroid Disorders and Diabetes Mellitus: Double Trouble. J Dia Res Ther. 2016; 2(1), doi: 10.16966/2380-5544.113.

52. Palma CC, Pavesi M, Nogueira VG, et al. Prevalence of thyroid dysfunction in patients with diabetes mellitus. Diabetol Metab Syndr. 2013; 5(1): 58, doi: 10.1186/1758-5996-5-58, indexed in Pubmed: 24499529

53. Kordonouri O, Charpentier N, Hartmann R. GADA positivity at onset of type 1 diabetes is a risk factor for the development of autoimmune thyroiditis. Pediatr Diabetes. 2011; 12(1): 31-33, doi: 10.1111/j.1399-5448 .2010.00666.x, indexed in Pubmed: 20723098.

54. Kadiyala R, Peter R, Okosieme OE. Thyroid dysfunction in patients with diabetes: clinical implications and screening strategies. Int J Clin Pract. 2010; 64(8): 1130-1139, doi: 10.1111/j.1742-1241.2010.02376.x, indexed in Pubmed: 20642711.

55. Ahmed A, Waris A, Naheed A, et al. Diabetic Retinopathy and its Correlation with Thyroid Profile and Anti Thyroid Antibodies. IOSR-JDMS 2017; 16(1): 96-98, doi: 10.9790/0853-1601079698.

56. Kordonouri O, Deiss D, Danne T, et al. Predictivity of thyroid autoantibodies for the development of thyroid disorders in children and adolescents with Type 1 diabetes. Diabet Med. 2002; 19(6): 518-521, do 10.1046/j.1464-5491.2002.00699.x, indexed in Pubmed: 12060066.

57. Kordonouri O, Hartmann R, Deiss D, et al. Natural course of autoimmune thyroiditis in type 1 diabetes: association with gender, age, diabetes duration, and puberty. Arch Dis Child. 2005; 90(4): 411-414 doi: 10.1136/adc.2004.056424, indexed in Pubmed: 15781936

58. Lindberg B, Ericsson UB, Ljung R, et al. High prevalence of thyroid autoantibodies at diagnosis of insulin-dependent diabetes mellitus in Swedish children. J Lab Clin Med. 1997; 130(6): 585-589, doi: 10.1016/s0022-2143(97)90108-6, indexed in Pubmed: 9422332

59. Gursoy NT, Tuncel E. The relationship between the glycemic control and the hypothalamus-pituitary-thyroid axis in diabetic patients. Turk J Endocrinol Metab. 1999; 4: 163-168.

60. Ortiz-Caro J, Obregón MJ, Pascual A, et al. Decreased T4 to T3 conversion in tissues of streptozotocin-diabetic rats. Acta Endocrinol (Copenh). 1984 106(1): 86-91, doi: 10.1530/acta.0.1060086, indexed in Pubmed: 6328820.

61. Bagchi N, Palaniswami N, Desai H, et al. Decreased thyroidal response to thyrotropin in type II diabetes mellitus. Metabolism. 1988; 37(7) 669-671, doi: 10.1016/0026-0495(88)90088-1, indexed in Pubmed: 3133539.

62. Rezzonico J, Rezzonico M, Pusiol E, et al. Introducing the thyroid gland as another victim of the insulin resistance syndrome. Thyroid. 2008 18(4): 461-464, doi: 10.1089/thy.2007.0223, indexed in Pubmed: 18346005

63. Ayturk S, Gursoy A, Kut A, et al. Metabolic syndrome and its components are associated with increased thyroid volume and nodule prevalence in a mild-to-moderate iodine-deficient area. Eur J Endocrinol. 2009; 161(4): 599-605, doi: 10.1530/EJE-09-0410, indexed in Pubmed: 19633072

64. Chutia H, Bhattacharyya H, Ruram AA, et al. Evaluation of thyroid function in type 2 diabetes in north-eastern part of India: A hospital-based study. J Family Med Prim Care. 2018; 7(4): 752-755, doi: 10.4103/jfmpc. jfmpc 292 17, indexed in Pubmed: 30234048.

65. Martino E, Seo H, Lernmark A, et al. Ontogenetic patterns of thyrotropin-releasing hormone-like material in rat hypothalamus, pancreas, an retina: selective effect of light deprivation. Proc Natl Acad Sci USA. 1980 77(7): 4345-4348, doi: 10.1073/pnas.77.7.4345, indexed in Pubmed: 6776526

66. Mendoza A, Hollenberg AN. New insights into thyroid hormone action. Pharmacol Ther. 2017; 173: 135-145, doi: 10.1016/j.pharmthera.2017.02.012, indexed in Pubmed: 28174093.

67. Pinazo-Durán MD, Pons-Vázquez S, Gallego-Pinazo R, et al. Thyroid hormone deficiency disrupts rat eye neurodevelopment. Brain Res. 2011; 1392: 16-26, doi: 10.1016/j.brainres.2011.04.005, indexed in Pubmed: 21529787.
68. Kocaturk T, Ergin K, Cesur G, et al. The effect of methimazole-induced postnatal hypothyroidism on the retinal maturation and on the Sirtuin 2 level. Cutan Ocul Toxicol. 2016; 35(1): 36-40, doi: 10.3109/15569527.20 15.1007509, indexed in Pubmed: 25758293.

69. Waber S, Meister V, Rossi GL, et al. Studies on retinal microangiopathy and coronary macroangiopathy in rats with streptozotocin-induced diabetes. Virchows Arch B Cell Pathol Incl Mol Pathol. 1981; 37(1): 1-10, doi: 10.1007/bf02892551, indexed in Pubmed: 6116344.

70. Takiguchi Y, Satoh N, Hashimoto H, et al. Reversal effect of thyroxine on altered vascular reactivity in diabetic rats. J Cardiovasc Pharmacol. 1989; 13(4): 520-524, indexed in Pubmed: 2470987.

71. Ittermann T, Dörr M, Völzke H, et al. High serum thyrotropin levels are associated with retinal arteriolar narrowing in the general population. Thyroid. 2014; 24(10): 1473-1478, doi: 10.1089/thy.2014.0190, indexed in Pubmed: 25156414

72. Czarnywojtek A, Owecki M, Zgorzalewicz-Stachowiak M, et al. The role of serum C-reactive protein measured by high-sensitive method in thyroid disease. Arch Immunol Ther Exp (Warsz). 2014; 62(6): 501-509, doi: 10.1007/s00005-014-0282-1, indexed in Pubmed: 24794233.

73. Iitaka M, Miura S, Yamanaka K, et al. Increased serum vascular endothelial growth factor levels and intrathyroidal vascular area in patients with Graves' disease and Hashimoto's thyroiditis. J Clin Endocrino Metab. 1998; 83(11): 3908-3912, doi: 10.1210/jcem.83.11.5281, indexed in Pubmed: 9814467.

74. Kajdaniuk D, Marek B, Foltyn W, et al. Vascular endothelial growth factor (VEGF) - part 2: in endocrinology and oncology. Endokrynol Pol. 2011; 62(5): 456-464, indexed in Pubmed: 22069107.

75. Rizos CV, Elisaf MS, Liberopoulos EN. Effects of thyroid dysfunction on lipid profile. Open Cardiovasc Med J. 2011; 5: 76-84, doi: 10.2174/18741 92401105010076, indexed in Pubmed: 21660244.

76. Popescu T, Mota M. Dyslipidemia and hypertension in patients with type 2 diabetes and retinopathy. Rom J Intern Med. 2009; 47(3): 235-241, indexed in Pubmed: 20446438

77. Baskol G, Atmaca H, Tanriverdi F, et al. Oxidative stress and enzymatic antioxidant status in patients with hypothyroidism before and after treatment. Exp Clin Endocrinol Diabetes. 2007; 115(8): 522-526, doi: 10.1055/s-2007-981457, indexed in Pubmed: 17853336.

78. Rodacki M, Zajdenverg L, Dantas JR, et al. Should thyroid-stimulating hormone goals be reviewed in patients with type 1 diabetes mellitus? Results from the Brazilian Type 1 Diabetes Study Group. Diabet Med. 2014; 31(12): 1665-1672, doi: 10.1111/dme.12530, indexed in Pubmed: 24961827.

79. Rogowicz-Frontczak A, Pilacinski S, Chwialkowska AT, et al. Patients with diabetes type 1 and thyroid autoimmunity have low prevalence of microangiopathic complications. Endocrine. 2016; 51(1): 185-188, doi: 10.1007/s12020-015-0643-5, indexed in Pubmed: 26044140.

80. Glastras SJ, Craig ME, Verge CF, et al. The role of autoimmunity at diagnosis of type 1 diabetes in the development of thyroid and celiac disease and microvascular complications. Diabetes Care. 2005 28(9): 2170-2175, doi: 10.2337/diacare.28.9.2170, indexed in Pubmed: 16123485.

81. Schneider T, Meyerson L. Thyroid therapy in diabetic retinopathy. S Afr Med J. 1969; 43(14): 414-417, indexed in Pubmed: 5786233.

82. Sailesh S. The THOR Effect: Thyroid Hormone Offsets Retinopathy. J Endocrinol Thyroid Res. 2018; 3(1):555605, doi: 10.19080/jetr2018.03.555605.

83. Wu J, Yue S, Geng J, et al. Relationship between Diabetic Retinopathy and Subclinical Hypothyroidism: a meta-analysis. Sci Rep. 2015; 5: 12212, doi: 10.1038/srep12212, indexed in Pubmed: 26193340.

84. Borooah M, Phukan S. A study on relationship between severity of diabetic retinopathy and subclinical hypothyroidism. Int J Res Med Sci. 2017; 5(5): 1818-1822.

85. Porta M, Sjoelie AK, Chaturvedi N, et al. EURODIAB Prospective Complications Study Group. Risk factors for progression to proliferative diabetic retinopathy in the EURODIAB Prospective Complications Study. Diabetologia. 2001; 44(12): 2203-2209, doi: 10.1007/s001250100030, indexed in Pubmed: 11793022 